\title{
Analytical model of the behaviour a masonry structure reinforced with composite materials
}

\section{Lukasz J. Bednarz}

Faculty of Civil Engineering, Wroclaw University of Science and Technology, Ph.D C.E. lukasz.bednarz@pwr.edu.pl Jerzy Jasienko

Faculty of Civil Engineering, Wroclaw University of Science and Technology, prof. Ph.D C.E. jerzy.jasienko@pwr.edu.pl

\section{Andrzej Kadluczka}

Faculty of Architecture, Cracow University of Technology, prof. Ph.D Arch. andrzej.kadluczka@gmail.com

Abstract: The paper presents an attempt to describe and adapt models of work of masonry structures subjected to reinforcement treatments with composite materials. The formation of a particular failure model is related to the type of reinforcement and its location (extrados, intrados). The models given are not intended to be used for calculations but to illustrate the behaviour of the structure, and may form the basis for assessing the effects of reinforcement applied in other cases.

Key words: masonry, vault, arch, analysis, model, strengthening, composites

\section{Analitički model ponašanja zidane konstrukcije ojačane kompozitnim materijalima}

Sažetak: U radu je prikazan pokušaj opisivanja i prilagodbe modela rada zidanih konstrukcija podvrgnutih postupcima ojačanja kompozitnim materijalima. Formiranje određenog modela sloma je povezano s vrstom ojačanja i njegovim položajem (ekstradosi, intradosi). Dani modeli nisu predviđeni da se koriste za proračune, već da pokažu ponašanje konstrukcije, i mogu činiti osnovu za procjenu djelovanja ojačanja primijenjenog u drugim slučajevima.

Ključne riječi: ziđe, svod, luk, analiza, model, ojačanje, kompoziti 
Bednarz, L. J., Jasienko, J., Kadluczka, A.

Analytical model of the behaviour a masonry structure reinforced with composite materials

\section{INTRODUCTION}

In the last few years there has been a growing interest in new technologies and techniques useful in the repair of structures, including masonry structures. Modern methods of repairing and strengthening masonry structures or their individual, particularly demanding elements (e.g. arches, vaults, domes, walls) offer the potential for significant savings and often the preservation of buildings of cultural heritage.

When traditional methods prove insufficient, the strengthening of historic buildings using modern conservation, construction and engineering techniques is permitted, provided that the principles of conservation doctrine are maintained and modern techniques are based on research and experience. Thus, in addition to conventional repairs using steel stringers, reinforced concrete shells, glued and screwed steel elements, composite materials based on various types of fibers, super-strong and ultra-thin steel tendons embedded in non-reactive mortars based on route binders or deformable polymers are increasingly being used for repair and stabilization.

Structural masonry elements need to be repaired and reinforced for a variety of reasons, such as: displacement of foundations, changes in soil and water conditions, changes in moisture content, atmospheric influences, inappropriate geometry and cross-section of elements, ageing of materials, rheological phenomena or the influence of exceptional load situations. Rehabilitation and strengthening of damaged structural elements are part of an overall repair programme and are closely linked to the issues of stabilization and consolidation of the structure. Reinforcement and stabilization aim at restoring the capacity of structural systems to fulfil specific service functions, to increase their static-strength properties and to make them resistant to destructive processes by, for example, consolidating the structure of the structural material or adding new elements.

The reinforcement and repair of brick structures is a difficult task, usually requiring a different approach in each case. For this reason, further research is needed, especially that carried out on technical scale models and using innovative technologies.

\section{STRENGTHENING METHODOLOGY}

Traditional strengthening methods, such as sprayed concrete or additional reinforced concrete or steel structures, increase the load-bearing capacity and stiffness of the structure. They may also cause irreversible changes to the esthetics of the monument and are unacceptable to conservators. If it is necessary to significantly increase the load-bearing capacity of a reinforced historic structure, composite materials based on different types of fibers can be used. Composites based on carbon fibers, aramid fibers, basalt fibers, polyparafenilenebenzobisoxazole (PBO), glass or boron fibers or even natural fibers from hemp, jute or flax are an important alternative to traditional forms of reinforcing structural elements. Composites based on natural fibers match the need for eco-friendly materials. Their very low production and processing costs and the ease of obtaining base materials argue in favor of their use in the case of the possibility to use composites that do not require high-strength fibers. The problem of using environmentally friendly materials is due to their low tensile strength compared to other materials. However, the positives - more favorable recyclability and reduced $\mathrm{CO}_{2}$ production - should be noted.

A wide range of possibilities of selecting the appropriate form of modern composite material in the form of: tapes, rods, mats, fabrics or mesh makes it possible to optimize the decisions made in relation to a specific structure. Mechanical properties of fibers used for reinforcements make it possible to use composite strengthening to reduce tensile and 
Bednarz, L. J., Jasienko, J., Kadluczka, A.

Analytical model of the behaviour a masonry structure reinforced with composite materials

bending stresses and thus make it possible to increase the load acting on a constructional element. Fibre composite materials are ideal for repairing existing heritage structures and providing them with an appropriate level of safety. And in the case of mineral matrix composites without epoxy resin, they are even ideal for heritage structures.

\section{DAMAGE MODEL BASED ON THE ANALYSIS OF THE FORMATION OF ARCH FAILURE MECHANISMS}

During the experimental tests conducted on the models on a technical scale undertaken at Wrocław University of Science and Technology [1-3] (fig. 1 - 2) and by other authors [4-6], different collapse mechanisms (fig. 3- 6) were observed in the arches reinforced by various methods (mainly on the extrados side). Three types of bonds between the particular segments in the cross section can be distinguished (fig. 5).

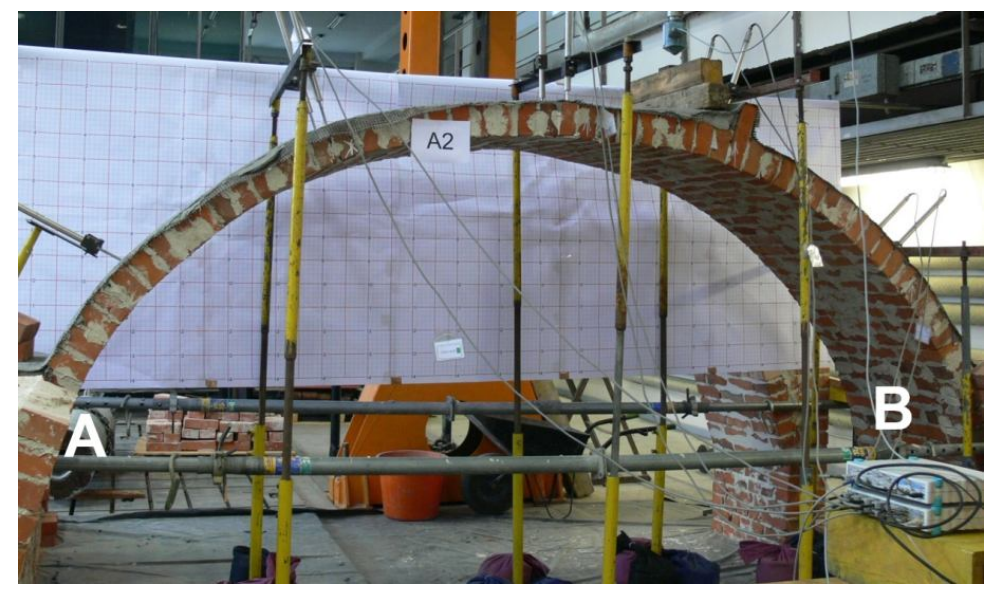

(a)

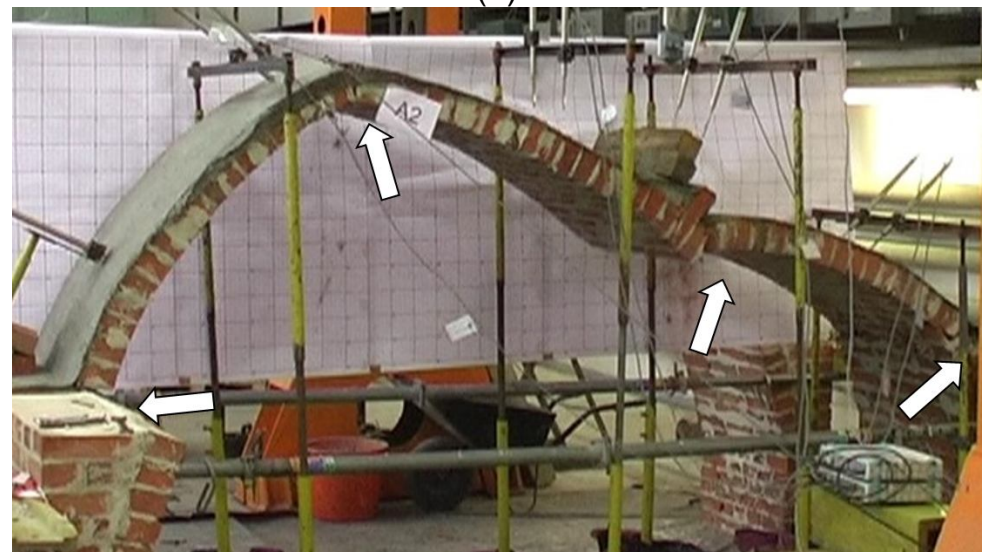

(b)

Figure 1. Arch reinforced with FRCM composite material, (a) before damage, supports $A$ and $B$ described, (b) during damage, photo by $Ł$. Bednarz 


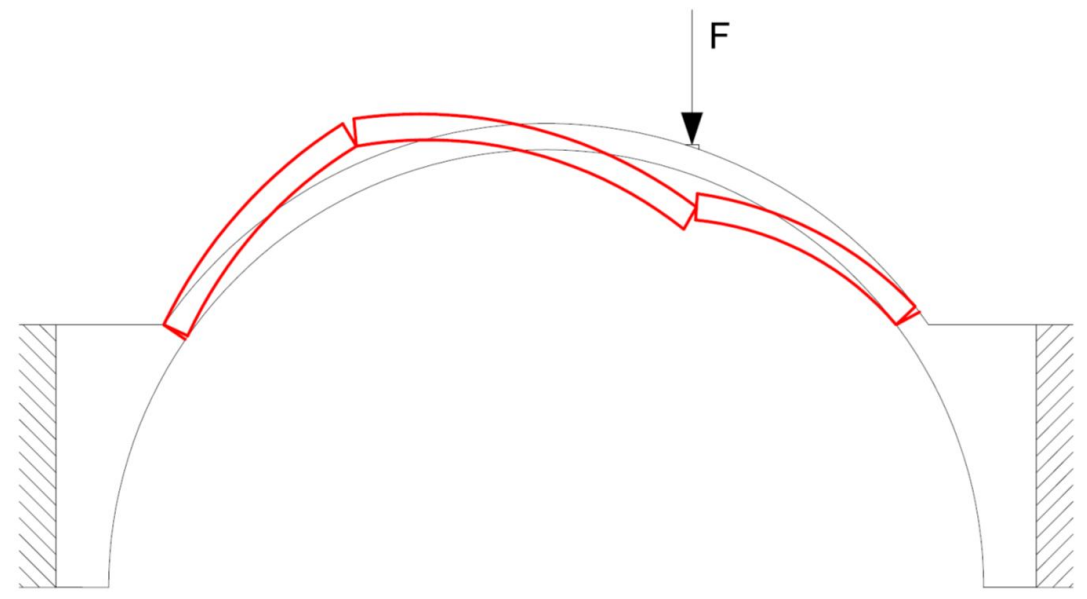

Figure 2. A model of the collapse of arch reinforced with FRCM composite material with the formed hinges

The different combinations of bond failure lead to different collapse mechanisms. If one of the bonds fails (e.g. during the formation of a hinge), the number of bonds between the bricks (segments) decreases $(z=-1)$. Hence one can write the following relation for arch stability:

- arch collapse $\quad-p-z<0$

- arch structure remains stable $\quad-p-z \geq 0$

where: $p$ - the number of original bonds between the particular bricks (segments), $z-$ the number of failed bonds between the particular bricks (segments) in the whole arch.

The arch collapses only when the number of failed bonds ( $z$ ) exceeds or is equal to the number of original bonds ( $p$ ) (in the considered case, $p=3$ ).

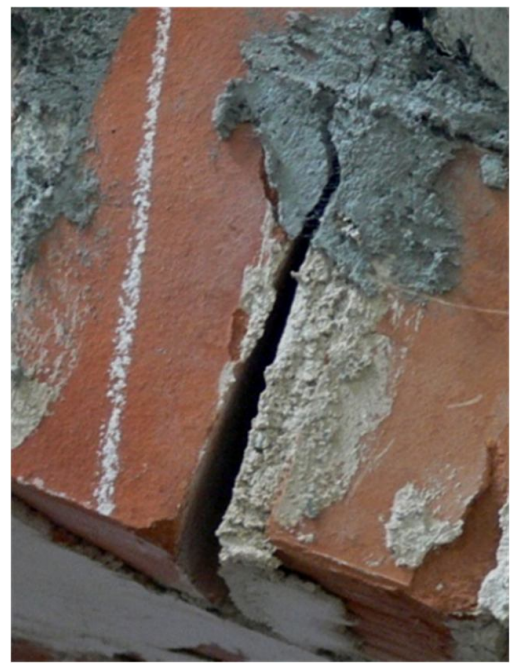

Figure 3. The formation of a joint with a center of rotation in the upper part of the joint, photo by Ł. Bednarz

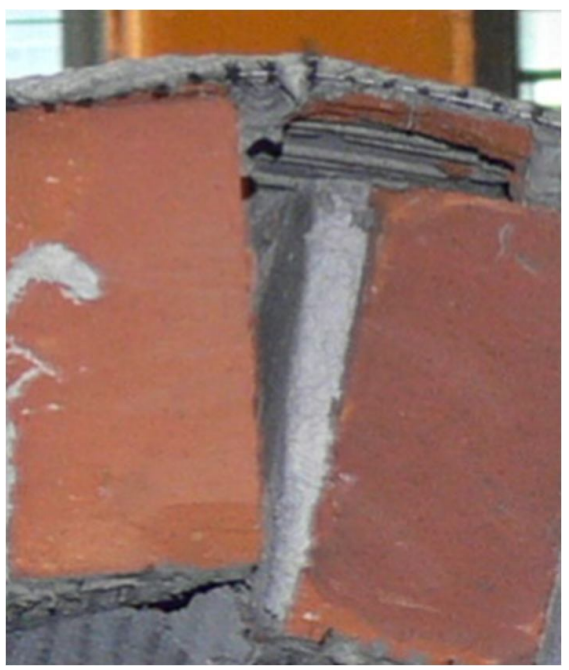

Figure 4. The formation of a joint with a center of rotation in the lower part of the joint, photo by $Ł$. Bednarz 
Bednarz, L. J., Jasienko, J., Kadluczka, A.

Analytical model of the behaviour a masonry structure reinforced with composite materials

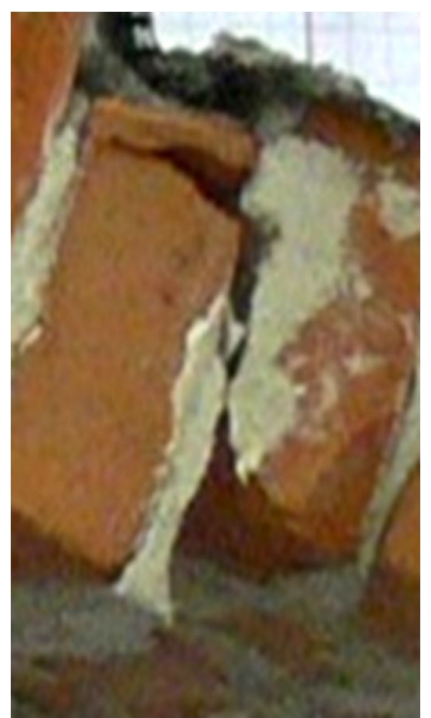

Figure 5. Shearing of the joint between the bricks, photo by Ł. Bednarz

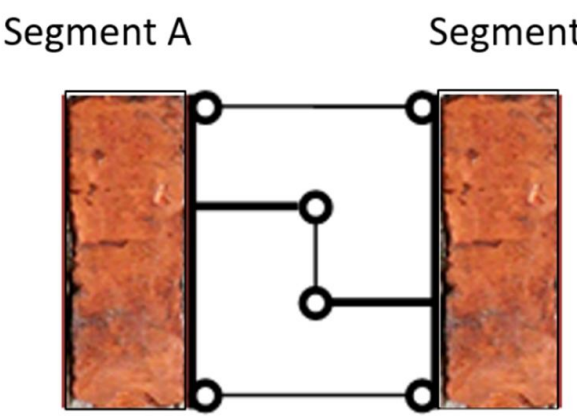

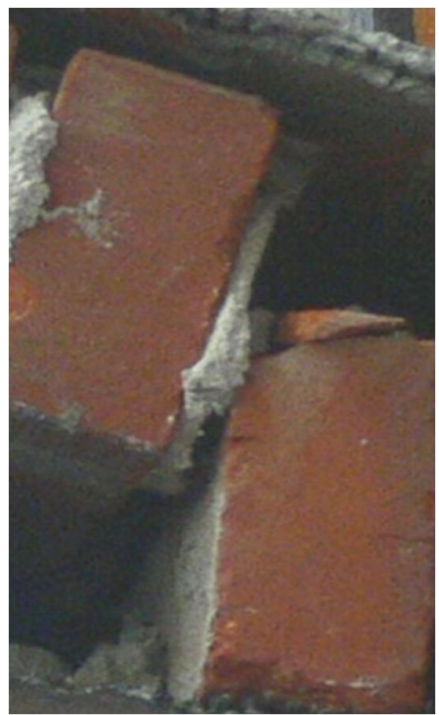

Figure 6. Shearing of the joint between the bricks combined with rotation, photo by $Ł$. Bednarz

Figure 7. Bond between bricks (segments)

\section{ANALYTICAL ANALYSIS}

Different mechanisms of failure of the bonds between the bricks were observed in the course of the tests [1-6]. Five cases of the mechanism can be distinguished:

1. the formation of a hinge reducing the number of bonds $(z)$ by $1(z=1)$, with the centre of relative rotation located in the bond's top part (fig. 8);

2. the formation of a hinge reducing the number of bonds by $1(z=1)$, with the centre of relative rotation located in the bond's bottom part (fig. 9);

3. the formation of a shear in the plane between segments, reducing the number of bonds by $1(z=1)$ (fig. 10);

4. the formation of a shear in the plane between segments and a hinge with the centre of relative rotation in the bond's top part, reducing the number of bonds by $2(z=2)$ (fig. 11$)$; 
Bednarz, L. J., Jasienko, J., Kadluczka, A.

Analytical model of the behaviour a masonry structure reinforced with composite materials

5. the formation of a shear in the plane between segments and a hinge with the centre of relative rotation in the bond's bottom part, reducing the number of bonds by $2(z=2)$ (fig. 12).

An analysis of the above collapse mechanisms shows that the arch collapses not only when failures occur between segments (bricks) in as many as four cross sections, representing cases 1-3 (e.g. 3-1-1-1-1=-1), but also when failures occur between segments in merely two cross sections, representing cases 4-5 (e.g. 3-2-2 = -1). Also an arch collapse caused by the failure of one of the intersegmental bonds in three places, being a combination of the above cases (e.g. 3-2-1-1=-1), is observed.

It follows from the analysis that the occurrence of a specific type of collapse is connected with the kind of reinforcement and its location (on the extrados or intrados).

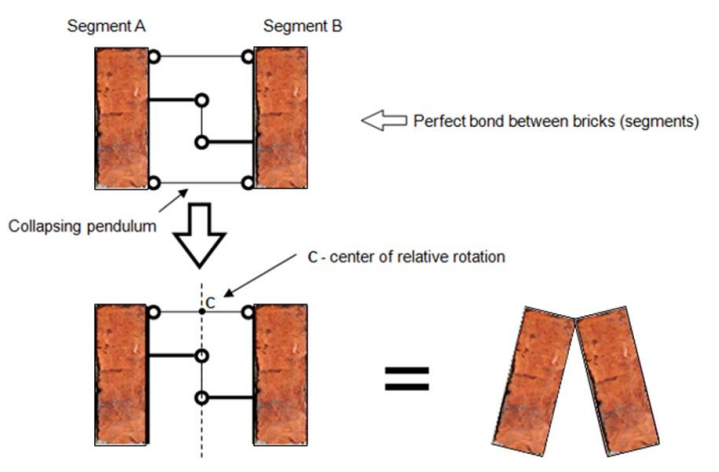

Figure 8. Hinge generating mechanism centre of relative rotation located in top part of bond

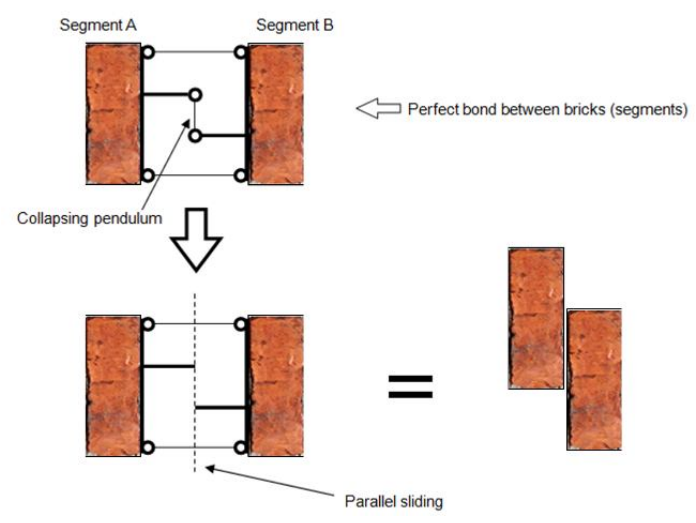

Figure 10. Sliding in plane generating mechanism between segments

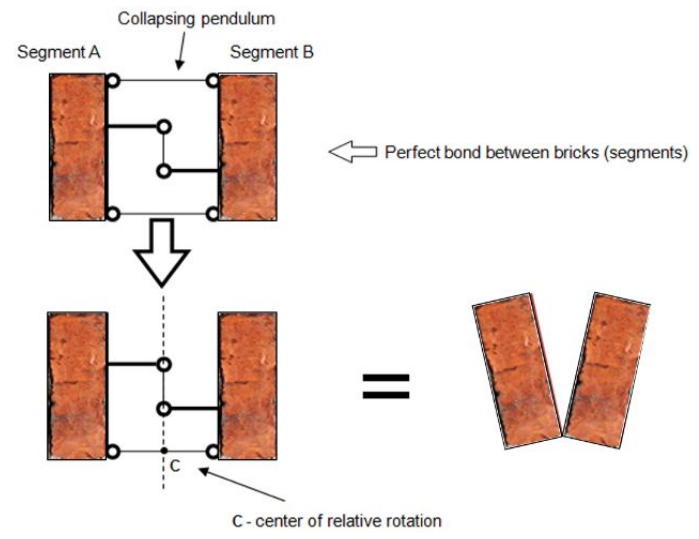

Figure 9. Hinge generating mechanism centre of relative motion in bottom part of bond

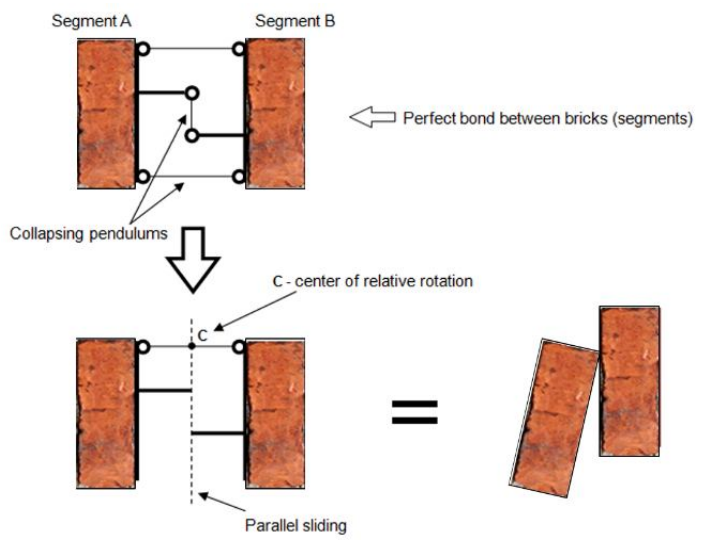

Figure 11. Shear in plane generating mechanism between segments and hinge with centre of relative rotation in top part of bond 


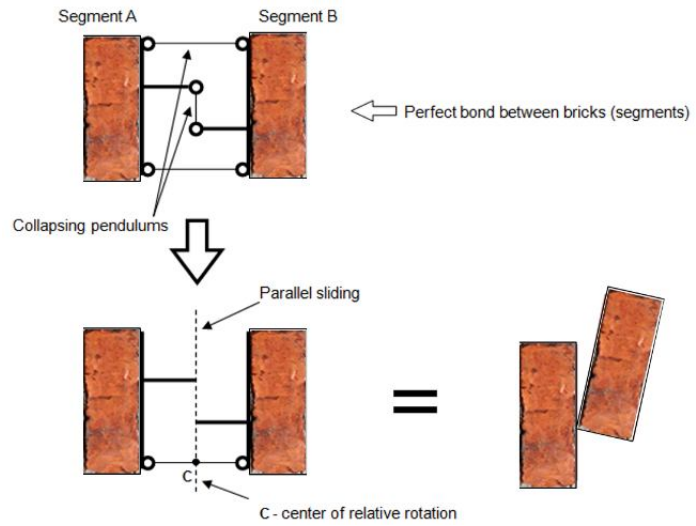

Figure 12. Shear in plane generating mechanism between segments and hinge with centre of relative rotation in bottom part of bond

In the case of delamination of the reinforcement with the composite material from the brick shell, before the destruction of the cross-section, a mechanism of joint formation different from that proposed in Figs. 8 - 12 is created. Therefore, it is possible to propose in the reinforced plane the formation of an elastic joint at the junction of two bricks (segments) as in Fig. 13 - allowing the left and right parts of the model to rotate.

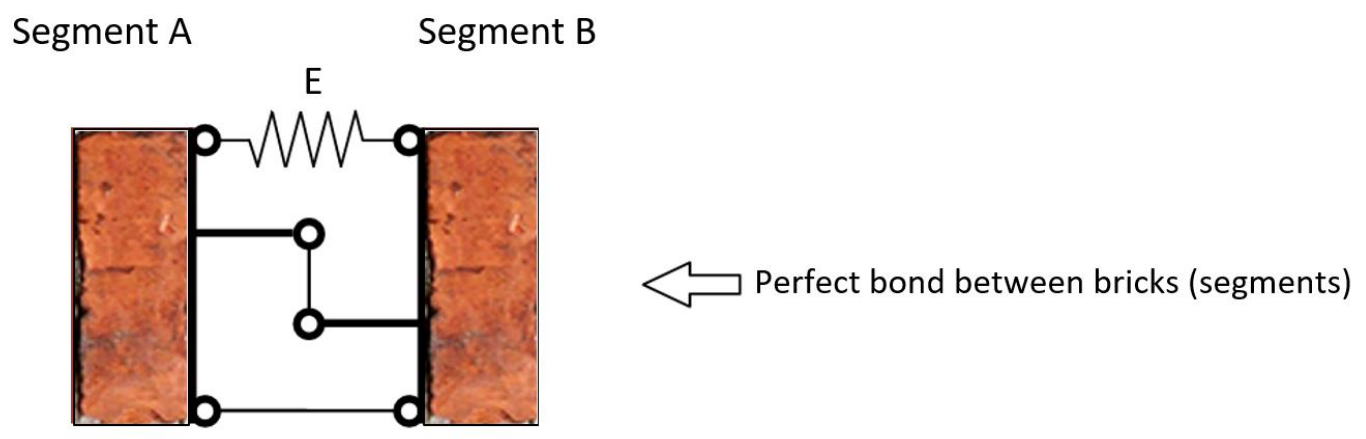

Figure 13. Proposed model of connection (bonding) between bricks (segments)

The proposed model of the connection, taking into account the formation of an elastic joint of susceptibility $E$, at the place of reinforcement, will enable the formation of rotation. However, the creation of rotation causes a situation in which other parts of the model of the arch structure will begin to form joints (with a rigid or elastic scheme) turning the whole structure into a "mechanism" and, consequently, causing the failure of the arch. Developing this course of action, it can be stated that the reinforced masonry element works in three phases. 
Bednarz, L. J., Jasienko, J., Kadluczka, A.

Analytical model of the behaviour a masonry structure reinforced with composite materials

\subsection{Phase I}

Before the brick section is cracked, it can be assumed that linear compressive and tensile stresses due to the normal force $\mathrm{N}$ and bending moment $\mathrm{M}$ are present throughout the section. An equivalent section can be considered here, after changing the reinforcement to an equivalent section of homogenised brickwork (Fig. 13) using the method contained in [7] for determining the equivalent reduced section, (Fig. 14).
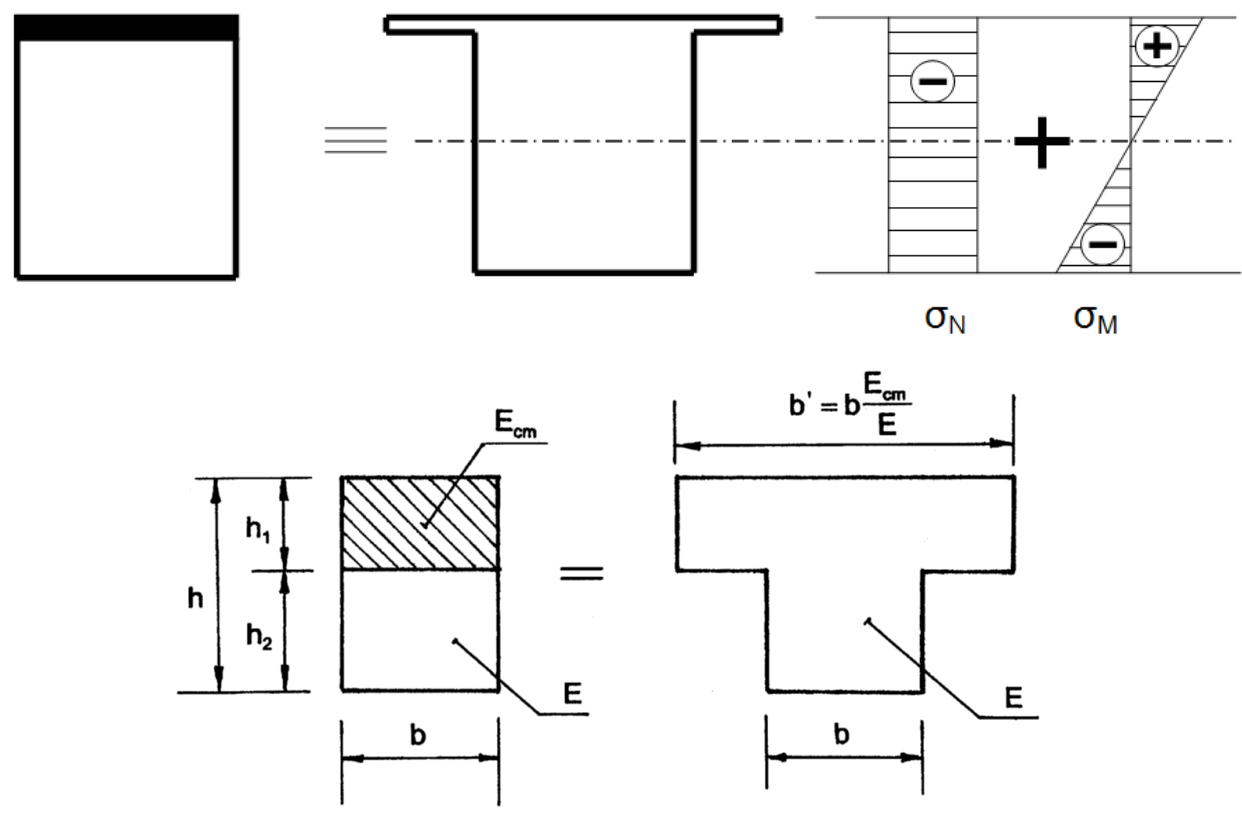

Figure 14. Equivalent section of reinforced masonry (Method of determining the equivalent reduced section)

\subsection{Phase II}

After the masonry section is cracked in the tension zone, the tensile stresses are transferred by the "reinforcement" which, outside the cracked section, is not detached from the masonry and works in the elastic range. The compression zone has a variable height $x$. A model of the section working in phase II is shown in Fig. 15.

The spring $E_{2}$ is working in phase II. The friction force $T$ on the slider in the model represents the shear strength of the mortar joint in the vicinity of the cracked section in the masonry, (Fig. 15). Spring $\mathrm{E}_{3}$ represents the elasticity of the masonry. 


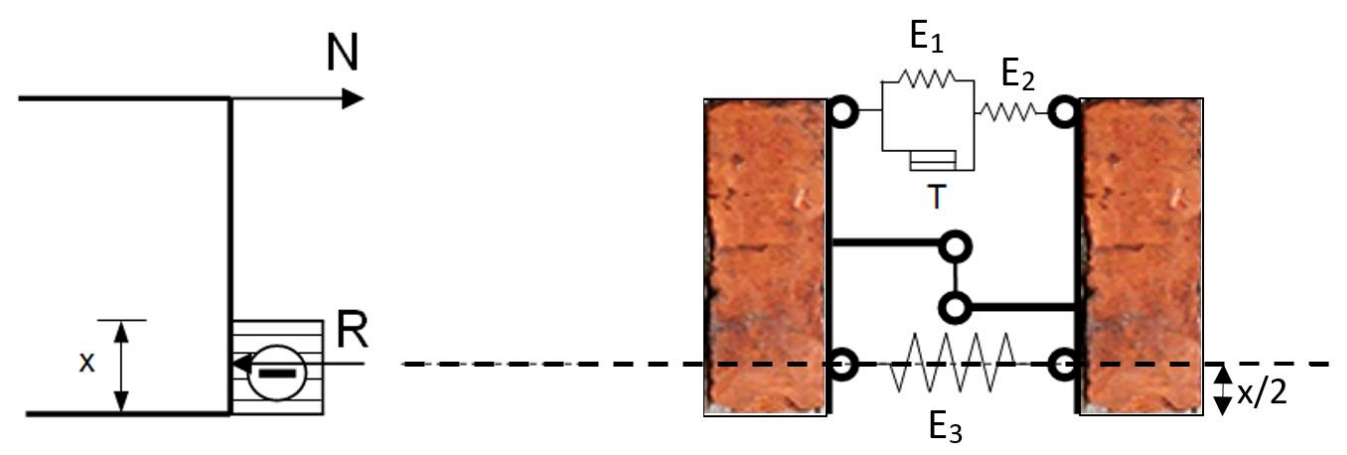

Figure 15. Model of a cross-section working in phase II

When the mortar strength between the reinforcement and the masonry in the area of the joint in the masonry (the outlined section - Fig. 16) is exceeded, i.e. the load capacity $T$ of the slider in the model (Fig. 15) is exceeded, a shearing of the joint will occur at the section a to the left and right of the outlined section of the masonry.

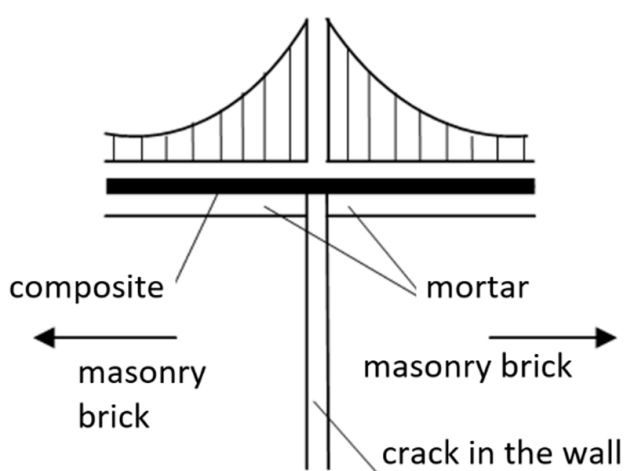

(a)

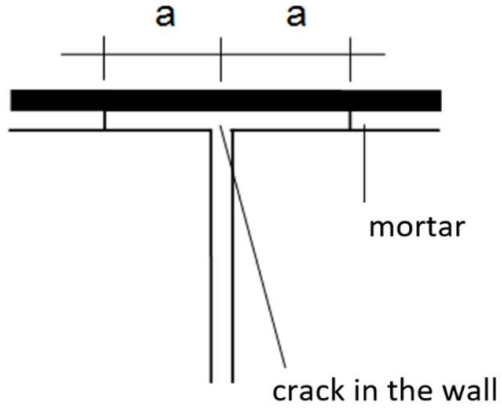

(b)

Figure 16. Detail of element connection, (a) stress diagram of the reinforcement, (b) destroyed joint in section "2a"

\subsection{Phase III}

When the joint is sheared, there will be slippage on the slider. At the same time, there will be a large relative rotation of the cross-section and the lower bond will move stepwise downwards (to the edge of the cross-section - Fig. 16). 
Bednarz, L. J., Jasienko, J., Kadluczka, A.

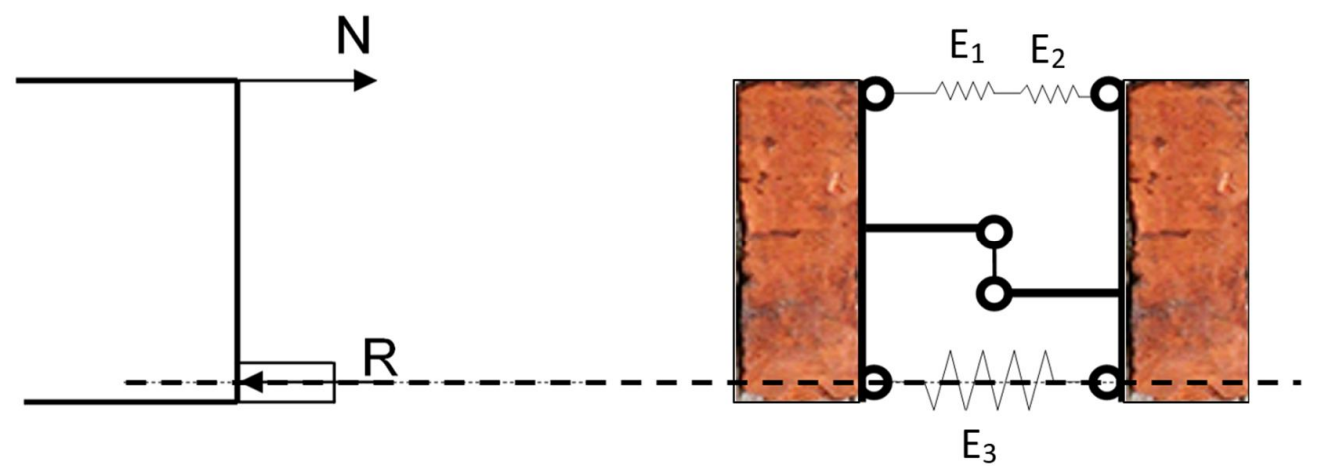

Figure 17. Model of a cross-section working in phase II

At the moment of sliding in the mortar, the slider does not work, but the serially connected springs $E_{1}$ and $E_{2}$ work. If, according to Fig. 17:

$$
F=E \cdot x
$$

where:

- F - force,

- E - spring susceptibility E,

- $x$ - extension of spring $E$,

then the two series springs $E_{1}$ and $E_{2}$ can be replaced by a single spring $E$ (Fig. 18), where:

$$
\frac{1}{E}=\frac{1}{E_{1}}+\frac{1}{E_{2}}
$$

where:

- E - spring susceptibility $E$,

- $E_{1}$ - spring susceptibility $E_{1}$,

- $E_{2}$ - spring susceptibility $E_{2}$.

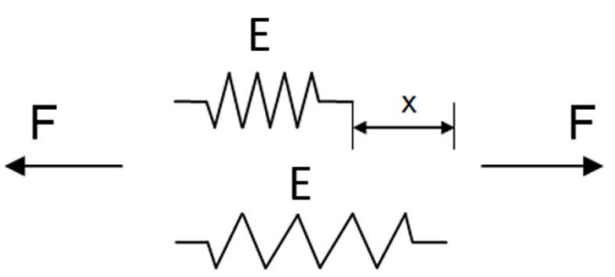

Figure 18. Spring E operation

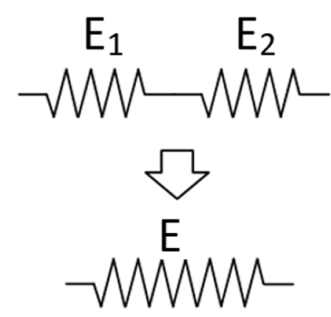

Figure 19. Series of springs replaced by a single spring

If the structure is not destroyed in phase III, a further sliding in the mortar by another section may occur. In this case, the model must adopt the arrangement as shown in Fig. 19.

The effect of creep may also be introduced into the model. It may be the case that no load increment occurs in phase III. As a result of reinforcement creep, the mortar in the joint 
Bednarz, L. J., Jasienko, J., Kadluczka, A.

Analytical model of the behaviour a masonry structure reinforced with composite materials

between reinforcement and masonry may be destroyed. It can then be assumed that the tensile zone is modelled by a system as in Fig. 20, in which a damper $\eta$ is incorporated. When creep increases up to a certain value $\delta$, the slider will be activated (Fig. 21). If the force $F$ is large enough, or if there is an increase in force, the slider will react and there will be shearing of the mortar between the reinforcement and the masonry.

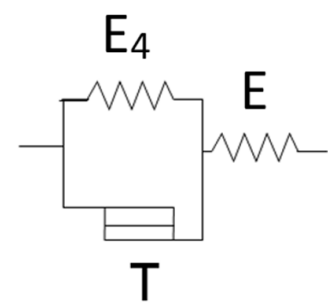

Figure 20. Spring arrangement in a possible Phase III model

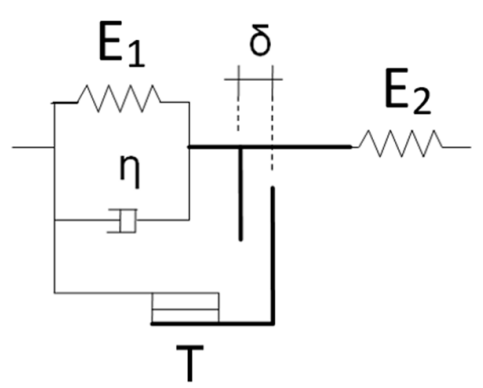

Figure 21. Tensile zone model

Such behaviour of brick arches was observed during experimental investigations. Further considerations should focus on determining the length of the anchorage zones and the elastic susceptibility of the individual composite materials used as reinforcement and on building an adequate computational model.

\section{CONCLUSIONS}

It should be noted that there is an important difference between the failure models for a cross-section with steel reinforcement and reinforcement made by composites, which have many times higher strength. In the equations for reinforced concrete or masonry sections reinforced with steel, it is assumed that there is no sliding between the material and the reinforcement at the time of failure. Hence, in cases where the failure of the cross-section occurs by rupture of the reinforcement, the steel strength at plasticization is included in the equations and formulas. If the reinforcement has such a high strength that the stresses in the reinforcement will always be significantly less than its strength, and at the same time the strength of the compression zone is also high, the section failure may occur by shearing of the layer between the reinforcement and the concrete (masonry). In such cases, the stress at which shearing (sliding) occurs between the reinforcement and masonry should be used in the equations and formulas instead of the breaking strength of the reinforcement. This stress may be much lower than the breaking strength of the reinforcement.

Based on the proposed solutions, it can be concluded that:

1) For the calculation of the bending capacity of a cross-section reinforced by composite materials (e.g. carbon fiber), the standard formulas from [7] cannot be used, which assume $f_{y d}$ as the breaking strength of the fiber reinforcement. This strength, assumed in the work as $f_{s} \approx 4800 \mathrm{MPa}$ cannot be achieved because it is too high.

2) The assumption of $f_{y d}$ as an ad hoc strength requires the hypothesis that the reinforcement will not debond from the masonry (even if not ruptured), as in the case of reinforced concrete elements. 
Bednarz, L. J., Jasienko, J., Kadluczka, A.

Analytical model of the behaviour a masonry structure reinforced with composite materials

3) The "spring" models given are phenomenological models and are not used for calculations only to illustrate the behaviour of the structure, the working of the model. The parameters of these models can be determined by knowing $F_{s}$, a, elastic features and $f_{d}, N, M$.

4) After determining the shear strength between reinforcement and masonry for different reinforcement materials (e.g. mesh, strips and others), adhesive mortar, masonry, etc., it appears that the proposed analytical model would be feasible using the same design formulas as for steel reinforcement.

\section{REFERENCES}

1. Bednarz Ł.J., Górski A., Jasieńko J., Rusiński E.: Simulations and analyses of arched brick structures, Automation in Construction. 2011, No. 20 (7)

2. Bednarz $Ł$. J.: Static work of historic curved masonry structures subjected to repair and strengthening treatments, Ph.D. thesis, Library of Wrocław University of Science and Technology, 2008

3. Bednarz $Ł$. J., Drygała I., Dulińska J., Jasieńko J.: Study of Materials Behavior in a Monumental Vault Strengthened by a Carbon Net in a Mineral Matrix Subjected to Seismic Influence, Applied Sciences" 2021, No. 11 (3):1015

4. Krajewski P., Hojdys Ł.: Experimental studies on buried barrel vaults, International Journal of Architectural Heritage, 2015, Vol. 9, Iss. 7

5. Hojdys $Ł$., Krajewski P.: Laboratory tests on masonry vaults with backfill strengthened at the extrados, Key Engineering Materials, 2015, Vol. 624

6. Valluzzi M.R., Valdemarca M., Modena C.: Behaviour of bricks masonry vaults strengthened by FRP laminates, Int. J. Composites for Construction, 2001, 5(3)

7. EN 1996-1-1 Eurocode 6: Design of masonry structures - Part 1-1: General rules for reinforced and unreinforced masonry structures 